\title{
Receptum est in recipiente per modum recipientis: Traces of the Liber de causis in Early Kabbalah
}

\author{
Saverio Campanini \\ Università di Bologna \\ ק״יו בסבת הסבות ועילת העילות שהוא אין סוף ורמזוהו ז־ל באמרם אין שואלין מה

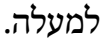 \\ SHEM TOV IBN GAON, Keter Shem Tov ${ }^{1}$
}

The study of the reception of the Liber de causis in Jewish thought could not be separated, as Jean-Pierre Rothschild aptly put it, "from a more comprehensive enquiry on the diffusion of Neoplatonism in Mediaeval Jewish Thought." ${ }^{2}$ Even if I had the required encyclopaedic competence to realize this inquiry, which is unfortunately far from being the case, I would lack the time and space for drawing a sketch of this vast phenomenon. Moreover, following Rothschild's assessment, it would be necessary to take into account possible influences of the Arabic Liber de causis for the epochs preceding its translations into Hebrew, alternative, now lost, translations into Hebrew (be it from Arabic or from Latin) and the practically endless field of the "tacit and widespread" presence of the book in Jewish thought. Nevertheless, well aware of the dimensions assigned to the present contribution, I should prefer to focus on a smaller chapter of the reception of the Liber de causis in the kabbalistic literature of the origins, with some prospective views on later developments. Rather than delusional completeness, I would like to propose a reflection, on the sound basis of selected case studies, on the significance and the function of the Liber de causis, in its various forms, for the beginnings of kabbalistic literature. At the same time,

1 Coriat 1839, f. 26a: “(...) even more so concerning the Cause of causes, that is En Sof, to which the sages of blessed memory alluded, saying that one should not inquire into what is above."

2 Rothschild 2013a, p. 81. On the necessity of a renewed study of the influence of the Liber de causis on early Kabbalah see the most recent intervention by Idel 2016, p. 157 . 
as it will become clear in the end of my contribution, I will hint to a possible, albeit paradoxical, effect of the Kabbalah upon the Liber de causis, examining how this text is transformed by its very adoption by the kabbalists.

The best-known case of reception of a sentence from the Liber de causis in kabbalistic literature is without doubt the passage quoted by Abraham Abulafia (second half of the XIII century) in his Imre shefer:

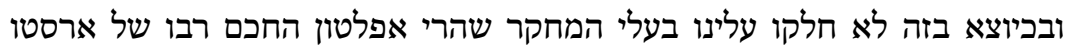

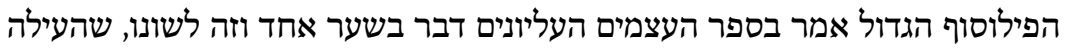

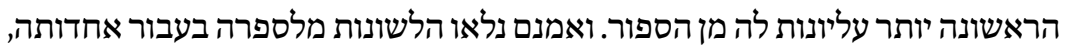

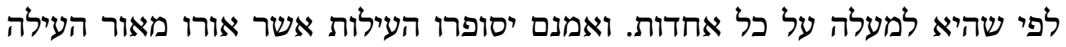

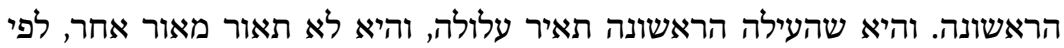

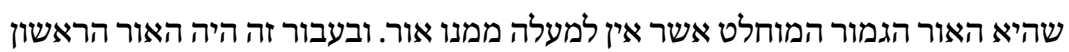

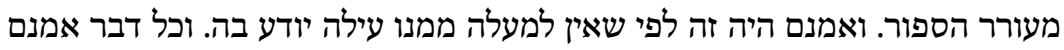

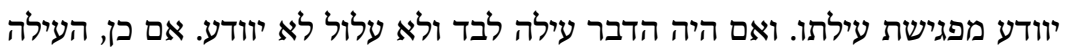

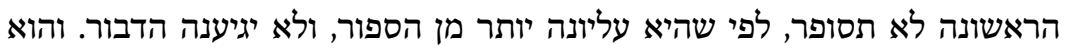

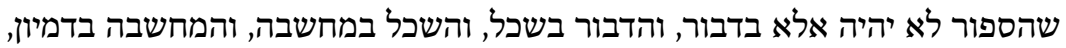

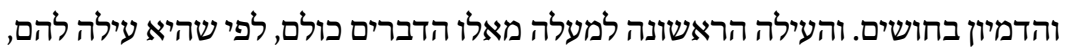

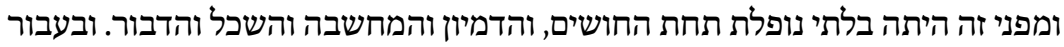

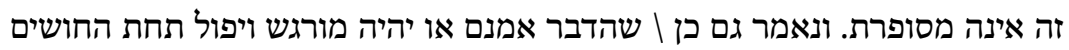

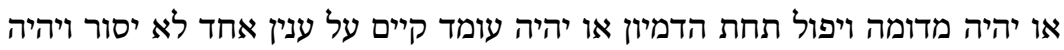

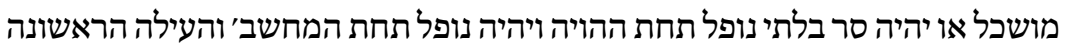

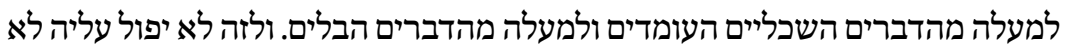

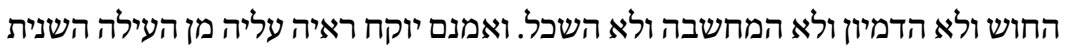

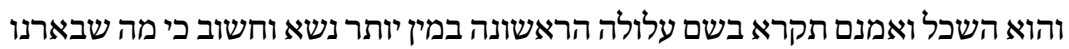
וגלינו. עד כאן דברי החכם הנכבד אפלטון.

In this sort of matter the philosophers (בעלי המחקר) are not in disagreement with us: the wise Plato, teacher of the philosopher Aristotle, in the book of the Highest Substances in a paragraph spoke about the matter, and here are his words: ${ }^{4}$ The first cause is above any description (narration). Tongues fail to describe it due to its unity since it is above every unity. What can be told are the causes deriving their splendour from the light of the first cause. This is because the first cause illuminates the effect but it itself is not illuminated by any other light since it is an absolutely perfect light above which there is no light. Therefore, the first light defies description. This is due to the fact that it has no cause through

3 Abraham ben Samuel Abulafia, Imre shefer, p. 193-194.

4 Here follows v(vi) of the Liber de causis. 
which it may be known. For everything is known and described through its cause. Therefore, if something is a cause only and not an effect, it is not known. If so, the first cause is not described since it is above description and no discourse can reach it, since every description is a discourse, and every discourse derives from intelligence, intelligence in turn derives from thought, thought from imagination and imagination from the senses. The first cause, however, is above all these things, since it is their cause, and for this reason it does not fall under the senses, imagination, thought, intelligence or discourse: therefore, it is beyond description. It is said furthermore that a thing is either sensible and falls under the senses or imaginable, falling under the imagination; either it is stable maintaining the same disposition and it is intelligible, or it is mutable und accidental, falling under the domain of thought, but the first cause is above the intelligible and the transitory, thus it does not fall under the senses, imagination, thought or intelligence. Thus, it can only be the object of an intuition through the second cause, which is intelligence. The latter is called first effect but in a higher and more elevated manner, as we have explained and revealed. These are the words of the venerable sage Plato.

It is interesting to observe, though, that the discovery of this quotation in secondary literature, proceeded backwards, that is to say that the first mentions of this passage which fell under the magnifier of philologists or bibliographers in the XIX century were indirect and much later ones. This path, from the estuary to the source, is not only typical, and understandably so, of philology, but it characterizes already the kabbalistic reception of the Liber de causis, in a way that cannot be the mere effect of chance.

The first hint towards an independent tradition of the Liber de causis, even before it was recognized as mediated by Abulafia, was detected by Moritz Steinschneider in $1863,{ }^{5}$ in a passage of Joseph Del Medigo's kabbalistic work bearing the title Sefer Novelot Chokmah, printed in Basel in $1631 .{ }^{6}$ Right from the beginning Steinschneider recognized that the passage quoted by Del Medigo was taken verbatim (with only minor cuts) from Isaac Abravanel's commentary

5 Steinschneider 1863, p. 114, n. 8.

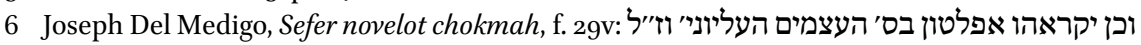

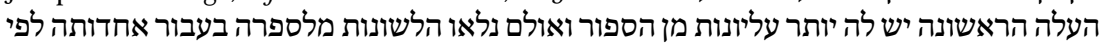

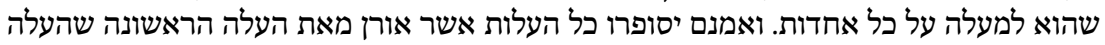

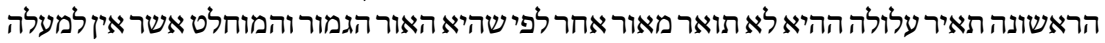

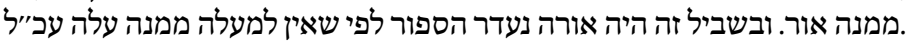


on the Pentateuch, and more precisely on the book of Exodus $(40,34)$, written in Venice about 1506 and printed for the first time there, in $1579 .{ }^{7}$ At first, however, Steinschneider wondered whether the source of this "Platonic" quotation might derive from a Christian author. Some years later, Steinschneider noticed that Abravanel must have derived his quotation from a contemporary kabbalist, Jochanan Alemanno, who, in his Sha'ar ha-chesheq, a large commentary on the Canticle, had quoted the $\mathrm{v}(\mathrm{VI})$ of the Liber de causis attributing the quotation to a certain "Zacharias", who had cited in his Imre shefer, that is to say "beautiful sayings," Plato's treatise "On the Highest Substances" (ha-'atzamim ha-'elyonim). ${ }^{8}$ Three elements of this bibliographic reference are actually leading astray: Plato is not Plato, Zacharias is not the real name of the author, the book "On the Highest Substances" is not otherwise known by this name, but the book Imre shefer does exist.

In 1869 Steinschneider, in his book on al-Fārābīi, ${ }^{9}$ referred the aforementioned passage from Alemanno, not from the published part of the book Chesheq Shelomoh, since it is not comprised in the excerpted edition available in print, ${ }^{10}$ but from a manuscript, which had been part of the collection of Isaac Samuel Reggio and had been subsequently purchased by Osias Heschel Schorr in 1847. The latter sold in 1869 many of his manuscripts to the Bodleian Library of Oxford with the help of Steinschneider, who received (in payment?) four manuscripts. ${ }^{11}$ One of them, as he states in his catalogue of the Royal Library of Berlin, ${ }^{12}$ was in Steinschneider's possession until he sold it to the Königliche Preussische Bibliothek, where it is still preserved. ${ }^{13}$ In a footnote of his book on al-Fārābī, Steinschneider copied Alemmano's quotation ${ }^{14}$ and

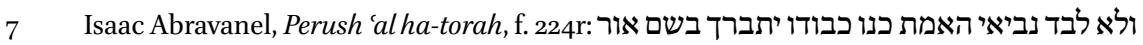

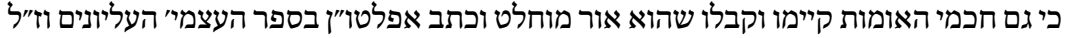

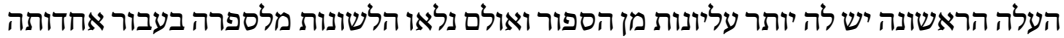

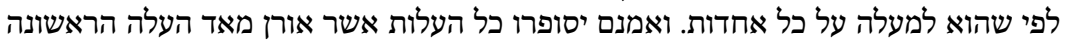

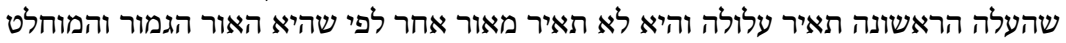

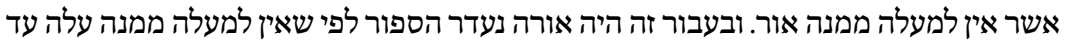
כאן. The passage had been noted and translated into Latin by J. Buxtorf jr., Exercitationes variae, Basel 1659, p. 121-122.

8 See also Scholem 1928-1929, then in Scholem 1931, p. 58.

9 Steinschneider 1869, p. 114-115.

10 First published in Leghorn 1790 and then in Halberstadt 1862.

11 Cfr. Richler 2012, p. 301-318.

12 Steinschneider 1897, p. $5^{-6 .}$

13 Sign. Qu. 832, Steinschneider's catalogue n. 143.

14 Steinschneider 1869, p. 114-115, n. 49:מאב אפלטון בספר העצמים העליונים כפי שהביאורו

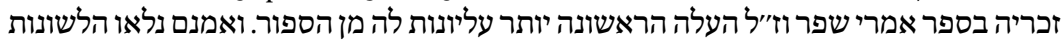

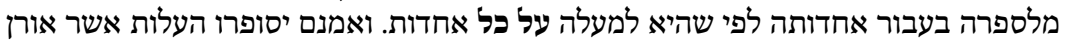


described the manuscript as still belonging to the collection of O.H. Schorr. ${ }^{15}$ At that point in time, Steinschneider expressed his hope to be able to check the quotation from the alleged author of the Imre Shefer, "Secharia," whom he recognized without hesitation as the Spanish Kabbalist Abraham Abulafia, author of a treatise bearing the same name and who used, among many other pseudonyms, also Zekariah, numerical equivalent of his first name. ${ }^{16}$ During the same 1869 Steinschneider traveled to Munich in order to, as he believed, put an end to his growing catalogue of the Hebrew Manuscripts of the Staatsbibliothek (since his catalogue was too voluminous, he had to work many years in order to squeeze it to the desired amplitude: the first edition appeared in $1875,{ }^{17}$ the second twenty years later $\left.{ }^{18}\right)$. And indeed, as he remarked in the Corrections and additions (Berichtigungen und Zusätze) at the end of the book on al-Fārābīi, ${ }^{19}$ he found the quotation in a Munich manuscript, containing the Imre Shefer by Abraham Abulafia. ${ }^{20}$ Right from the start, Steinschneider had recognized that the passage quoted, which seems to be the source of all the later authors we have mentioned, derives from the Liber de causis, bearing, in Abulafia's words, the unusual title of "Book of the Highest Substances." This awakened, in turn, the interest of Otto Bardenhewer, who studied the Hebrew translations of the Liber de causis in the end of his edition of the book, ${ }^{21}$ and dedicated some attention to Abulafia's quotation. ${ }^{22}$

מאור העלה הראשונה. והיא שהעלה הראשונה תאיר עלולה והיא לא תאור מאור אחר לפיר וביר

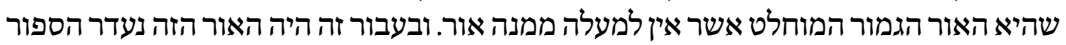

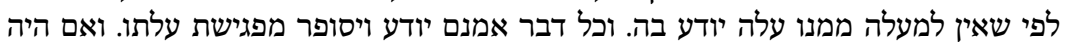

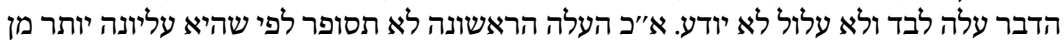

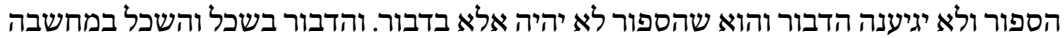

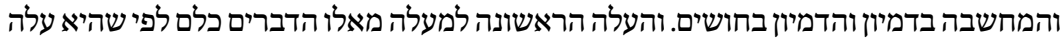

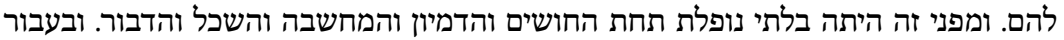

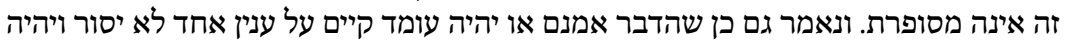

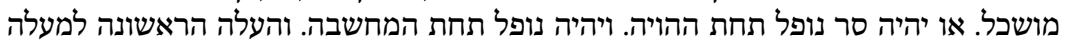

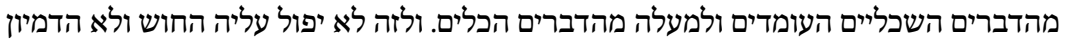

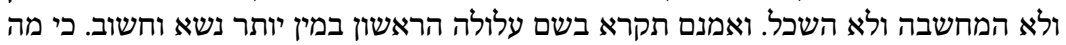

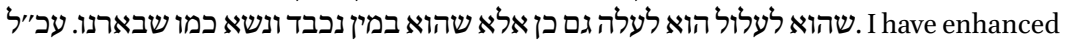
in boldtype my own readings, based on the manuscript, where they diverge from Steinschneider's.

15 Steinschneider 1869, ibid.: "Hs. Reggio's (jetzt Schorr's)".

16 In fact the numerical value of the letters forming the name זכריהו, that is 248 , coincides with the one resulting from אברהם; cfr. already Landauer 1845, col. 510.

17 Steinschneider 1875 .

18 Steinschneider 1895 .

19 Steinschneider 1869, p. 249.

20 In the ms Munich, Bayerische Staatsbibliothek, Cod. Hebr. 285, f. 114r-v.

21 Cfr. Bardenhewer 1882, p. 305-323.

22 Bardenhewer 1882, p. 319-320. 
Among the five known Hebrew versions of the Liber de causis, conscientiously studied by Jean-Pierre Rothschild, none could be said to be the source of Abulafia. It is evident that Abulafia depended from the Latin tradition of the work: in fact, he speaks of $3^{2}$ propositions, a subdivision of the text material which is not found in the Arabic mediated "original" of the Liber de causis and therefore he could not depend from the Hebrew translation (made approximately in the 8 os of the 13th century) by Zerachia Chen. ${ }^{23}$ The shorter version contained in the ms. 706 of the Bibliothèque Nationale de France, independently from any question of dating, could not be Abulafia's source since it only translates the propositions and not the commentary, which forms part of Abulafia's quotation. The two later Hebrew translations (made, respectively, by Judah Romano and Eli Chabillo), are out of the question since they have been completed after Abulafia's death. Only one Hebrew translation, attributed in all likeliness to Hillel of Verona's, could be Abulafia's source. There are two facts which are of peculiar interest in this context: Abulafia reports that he has been a pupil of Hillel, in Capua, about 126o and Hillel is the only one who attributes the propositions to Plato, as Abulafia does, although he suggests that Plato was the author of the propositions and "Abunasr" that is to say al-Fārābī, was the author of the commentary. Nevertheless, a quick comparison of the two translations shows that, against Bardenhewer's hypothesis, Abulafia did not use, if he ever knew it, Hillel's version. ${ }^{24}$ In other words, the most important fragment of the Liber de causis in kabbalistic literature, used many times over to justify the central doctrine of the sefirot and the negative theology of the first kabbalists down to the XVII century is independent from the philosophical reception of the same booklet. This does not mean that, in order to explain the vast reception of the Liber de causis within Jewish thought, its adoption in kabbalistic circles did not play a substantial role: quite the contrary

23 See Pseudo-Aristoteles Liber de causis (ed. Schreiber).

24 Hillel's version is attested in only one manuscript preserved at the Bodleian Library of Oxford, sign. Mich. 335 (olim 82), cfr. Neubauer 1886, col. 465-466, n. 1318. The text is published in Rothschild $2013 \mathrm{~b}$. To ease the comparison, I quote here the relevant passage,

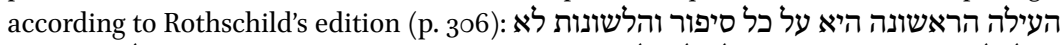
יוכלו לספרה בעבור שהיא על כל עילה. אמר המפרש הסבה בזה היא בעבור שכל סיפור היא סיאור

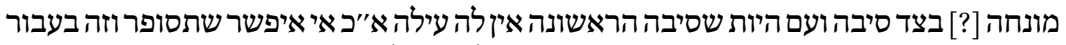
שהסיפור יעשה בעד דברור והדבור יעשה בעד שכל והשכל בעד נחשבה והמחשת נחשבה בעד חוש

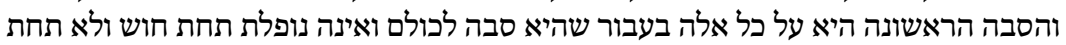

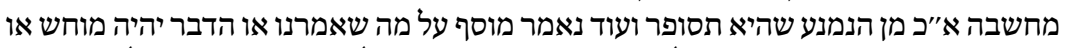

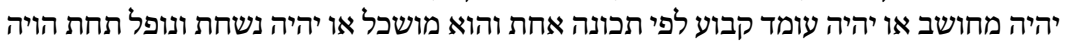

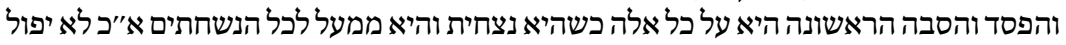
בה לא חוש ולא מחשבתים כלתולה. 
is the case, as it is shown, among other things, by the extant manuscripts of the Hebrew translations of the booklet, in which one of its versions is copied within kabbalistic miscellanies, and by the fact that at least for Hillel of Verona the contraposition between philosophy and Kabbalah was not a relevant one. ${ }^{25}$ As J.-P. Rothschild has recommended, it would certainly be worthwhile to investigate in which measure Kabbalah influenced the direct and indirect reception of the Liber de causis in Jewish thought, but I would prefer, on this occasion, to follow a different path which, if I am not mistaken, should nevertheless contribute to understand the ways of the Liber de causis within Jewish medieval literature. What I suggest to investigate is the function of explicit or implicit reference to the Liber de causis, be it understood as the work of Plato, of Aristotle, of Proclus or of al-Fārābī, within the emerging literature of Kabbalah.

Nevertheless, before studying one case in point, represented by an implicit quotation of the Liber de causis in a short kabbalistic treatise of 'Azri'el of Gerona, it seems appropriate to focus briefly on two important features of the text ${ }^{26}$ we have followed backwards to the "source" which is not older than the first Hebrew translations of the book, but certainly independent from them. The first point is of rather philological nature, and concerns the fact that Jochanan Alemanno demonstrably knew from other sources the Liber de causis, which he quotes repeatedly in his unpublished works and notebooks, ${ }^{27}$ and was even aware that this metaphysical treatise represented the thought of the Neoplatonic philosopher Proclus. ${ }^{28}$ This did not prevent him, out of respect for his source, Abulafia, to maintain the attribution to Plato in more than one circumstance. The second point deserving to be underlined is that the function of this relatively short quotation varies from author to author and, less surprisingly, from an epoch to the next. The most interesting "context" is undoubtedly the original one, offered by Abraham Abulafia. Immediately after the passage from the Liber de causis quoted above, and copied so many times afterwards, he writes:

25 Cfr. Hillel von Verona, Über die Vollendung der Seele.

26 Liber de causis, $\mathrm{v}(\mathrm{VI})$.

27 Cfr. Idel 1982, p. 6o-112; Idel 1983, p. 186-242. The same passage from the Liber de causis is quoted, with only minor textual variations, in Alemanno's Collectanea: Paris, BnF, hébr. 849, f. 91 (here, instead of Plato, the author of the passage is identified as "one of the sons of Yaphet", that is to say, a Greek) and f. 123r; Oxford, Bodleian Library, Neubauer n. 2234 (old sign. Reggio 23), f. 21r. See also Ogren 2016, p. 31.

28 See for example, Alemanno's work Chay ha-ólamim, ms. Mantua, Biblioteca Comunale, 21, f. 22v, where אפורוקלוס (Proclus) is explicitly quoted. 
וכתבתי לך כל מה שכללו בשער אחד שלם מעניינים אלה, להודיעך דעת הפילוסופים

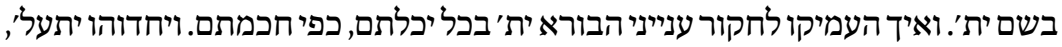

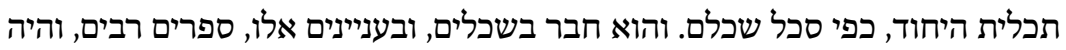

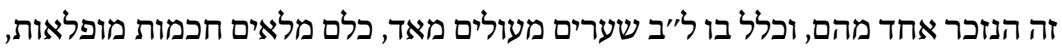
והם ראוים לכל מקובל לדעתם וכלל בוליב.

I have copied the entire contents of the paragraph concerning this subject in order to let you know what the philosophers think about the Lord, blessed be He, how deep they researched about the Creator, may He be exalted, with all their might, according to their wisdom, and how they proclaimed His perfect unity, according to the reach of their intellect. The author [Plato] wrote many books concerning the intellects and related subjects, and the one we have just quoted is among them: in it he gathered 32 truly excellent paragraphs, all of them containing wonderful treasures of wisdom, so that they are worth knowing for every kabbalist.

Abulafia states here openly that what "Plato" and the philosophers have to say about the ineffable "First Cause" is worth considering, since it confirms the doctrines of Kabbalah. In a different historical and cultural context, at the end of the XV century, Jochanan Alemanno bends the very same words quoted by Abulafia, as the proof that the sefirot (interpreted here as "narrations") one of the central tenets of Kabbalah, are to be considered in perfect accordance with "Plato," since he stated that the First Cause only is unspeakable (above any "narration"), implying that immediately after the First, the secondary causes, or the intelligences, or rather the Platonic Ideas, are to be closely identified with the sefirot. Abravanel, as Alemanno before him, pointed out the perfect compatibility with the doctrine of "Plato" with the teachings of Al-Ghazālī, against the doctrine of Averroes, but Abravanel underlines also that the very same doctrines are found in the Pardes rimmonim of Moses Cordovero, a classic of XVI century Kabbalah. In the XVII century Abraham Yagel, in his Bet Ya'ar ha-Levanon, quotes the very same text pointing out that its negative theology coincides largely with the kabbalistic doctrine and linking it also to Hermetic doctrines. ${ }^{30}$ The largest apologetical syncretism is undoubtedly to be found in Joseph Del Medigo, who recognized easily that the "Platonic" doctrine of the Liber de causis was in perfect harmony with Proclus, Plotinus, Al-Ghazālī, the kabbalists, but also, in describing the Ein sof as pure light, in accordance with

29 Abraham ben Samuel Abulafia, Imre shefer, p. 195.

$30 \quad$ Cfr. Idel 1983, p. 240, n. 206. See also Ruderman 1988, p. 130. 
the Bible, the Jewish exegetes (he names Rambam, Ibn Ezra and Ramban) and the most divine among the Christian sages. This universal concordance seems to go too far, but it defines perfectly, although through an exaggeration, the whole point of my present argument: the reception of the Liber de causis in this context, undoubtedly of kabbalistic origin, is always functional to some project of harmonistic, more than syncretistic nature. One cannot overlook the fact that the Liber de causis, as elsewhere the Theologia Aristotelis, serve the general purpose of reinforcing the legitimacy of kabbalistic innovations ad intra, and, ad extra, of integrating the authentic core of Jewish revelation in the language (be it cataphatic or, such as in this case, apophatic) of the other. ${ }^{31}$

\section{A Renaissance Intermezzo}

Before going back to early Kabbalah, a short intermission seems desirable at this point, in order to follow a trace of the Liber de causis, which becomes identified with Kabbalah in a thinker who was rather afraid of the confusion between Jewish tradition and Platonism, but had no major objection to articulate his thought in rigorous Aristotelic-Averroistic terms. I am referring to Elijah Del Medigo, who in 1486, commenting upon Averroes' De substantia orbis adds, as Idel already pointed out, ${ }^{32}$ a passage in which an allusion to the Liber de causis is very likely:

כי הם יאמינו שהאין סוף לא יפול בו שום מחשבה וציור ולא גבול ואפי' שכלי ואין לומ'

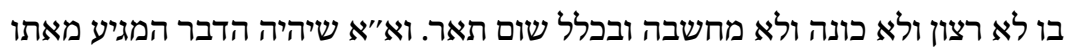

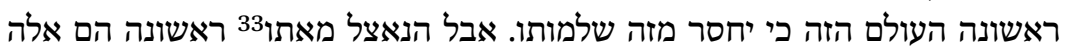

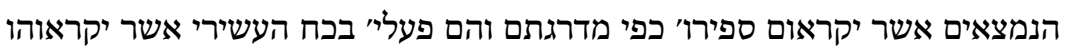

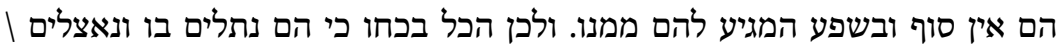

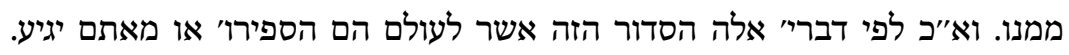

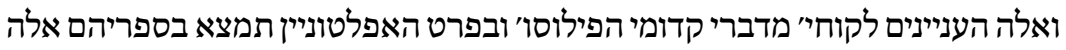

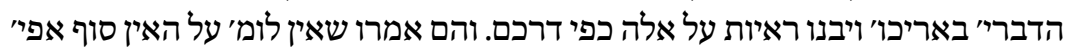
שם השכל כאשר זכר ב"ר בשמם בהפלת ההפלה וכאשר ידות ידוע לאשר ראה ספרי אלה לאלוף

31 For a further interesting chapter of the history of the reception of prop. $\mathrm{v}(\mathrm{VI})$ of the Liber de causis in Kabbalistic literature, see Scholem 1964, p. 46; then in Scholem 1970a, p. 50 quoting Vajda 1954, p. 64.

32 Idel 1983, p. 219.

33 The word ממנו is effaced here. 


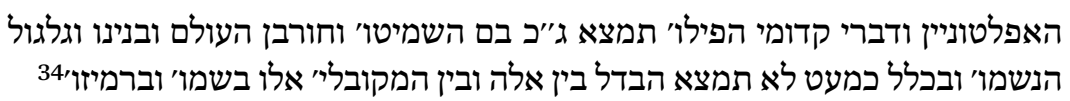

For they believe that thought and mental conception do not properly apply to En sof, neither does any definition, not even the one of intellect. Concerning it, neither volition, intention, thought nor, in general, may any attribute be said. Furthermore, it is impossible that this world be, at the outset, that which derives from it, since its perfection would thereby be rendered deficient. Instead, what emanates from it at the outset are those Existents which they term sefirot in accordance with their rank. These act by virtue of the force of the tenth one which they call En sof and by virtue of the emanating flux deriving from it. Consequently, everything exists by virtue of its force, since they all are contingent upon it and are emanated from it. Hence, according to their statements, the order of this world is either constituted by the sefirot or is derived from them. These notions are taken from the statements of the ancient philosophers, especially the Platonists. In their books, you will find these statements being expatiated. They construct proofs upon their basis, in accordance with their fashion. They asserted that one may not apply even the epithet of intellect to the En sof, as Averroes mentioned in their name in the Incoherence of the Incoherence ${ }^{35}$ and as it is known to whoever has seen the books of these Platonists, as well as the statements of the ancient philosophers. You will also find in them the doctrines of cosmic aeons- the destruction of the world and its restoration - as well as the doctrine of metempsychosis. And in general, you will find almost no difference between them and the kabbalists except for the divine epithets and cryptic allusions. $^{36}$

Del Medigo, who was no fan of the Kabbalah and certainly no Platonist, accuses the Kabbalists of having derived their idea of $E n$ sof and of the emanation of the sefirot from Plato and the ancient philosophers. Elijah del Medigo translated his commentary on the De substantia orbis also in Latin ${ }^{37}$ but the passage

34 Ms. Paris, BnF hébr. 968, f. 41r-v. The passage had been partly quoted in Idel 1982, p. 99, but the text contains several mistakes, which affect, as a consequence, also M. Gavarin's translation (in Idel 1983, p. 219). For a superior version, see Bland 1991, p. 52. Cfr. Averroes, Tahafut al-Tahafut, p. 186.

36 I quote here the translation of Bland 1991, p. 31-32.

37 His Latin version of the commentary is preserved in the ms. Vat. Lat. 4553 of the Vatican Library. 
quoted above is not yet present there. ${ }^{38}$ In any event, upon Pico's insistence on having Elia's opinion on Kabbalah, he translated the passage in the famous letter written between 1485 and $1486^{39}$ to his patron preserved in the ms. 6508 of the Bibliothèque Nationale in Paris. There (f. $75^{\mathrm{r}-\mathrm{v}}$ ), the missing passage is found:

Ipsi enim opinantur, quod sunt hic quedam entia, quorum gradus est inferior gradu dei gloriosi, quem vocant infinitum, que sunt fluxa, non dico facta neque producta, ab illo, quod vocant infinitum, et ipsa habent gradus diversos, et gradus horum superior est motoribus celorum, et corporibus celestibus sensibilibus. Et ordo, per quem producuntur entia producta et conservantur secundum ordinem, est per ista, scilicet çephiroth, idest numerationes, / sic enim vocant illa fluxa ab infinito. Ipsi namque credunt, quod in infinito nulla cadit cogitatio, neque aprehensio, neque terminus sive determinatio aliqua, vel dispositio etiam intellectualis, neque dicitur de ipso voluntas, neque intentio, neque cogitatio, et universaliter nulla dispositio, et impossibile est, ut sit res proveniens, seu fluxa ab ipso, scilicet infinito. ${ }^{40}$ Iste mundus nam esset diminutus secundum hoc, seu deficeret ab eo perfectio sua, sed primum fluxum ab ipso sunt ista entia, que diximus, secundum gradus eorum, que vocant çephiroth, ut diximus, et ipsa sunt agentia per virtutem dei, quem ipsi vocant infinitum, et per fluxum, qui provenit eis ab ipso, et ideo omnia sunt per virtutem illius. Nam ipsa, scilicet çephiroth, ${ }^{41}$ dependent ab ipso, et fluxa sunt ab ipso, scilicet infinito. Unde, secundum hos, ordo iste inventus in mundum est per illa çephiroth. Primum autem simpliciter quem vocant infinitum nulla dispositio, seu attributio positiva, dicitur de eo, ymmo neque ipsum volunt vocare intellectum, ut dicit etiam Averrois in libro Destructio destructionum, loquendo de attributis, seu proprietatibus, quod Plato seu quidam Platonici nolunt ${ }^{42}$ vocare deum intellectum, seu affirmare de ipso, quod est intellectus. Ipsis autem çephiroth posuerunt nomina propria, et motum fluxus seu dependentie, et deder-

38 I wish to express my gratitude to Giovanni Licata, who is preparing a critical edition of Del Medigo's Commentary on the De substantia orbis, for checking the Latin manuscript.

On the date of this latter and the complex problem of which of the two versions of the Commentary on the De substantia orbis has been composed first, see Busi 2006, p. 167196; Italian translation in Busi 2007, p. 25-45.

40 The words scilicet infinito are added on the margin.

41 The words scilicet çephiroth are added on the margin.

42 Here the word dicere is erased. 
unt secundum opinionem eorum causam, quare ista debent esse $\left[\mathrm{X}^{43}\right]$, neque plura, neque pauciora, et in his fecerunt libros et volumina. ${ }^{44}$

From the vantage point of an adversary of Kabbalah, as Elia del Medigo most probably was, ${ }^{45}$ it is easy to see the danger implicit in utilizing such material as the "Platonic" Liber de causis: it could lead to the venomous accusation of depending from "foreign wisdom", thus contaminating the purity of Biblical revelation. This explains perhaps the prudence with which the kabbalists, for enthusiastic they might be concerning the analogies of their doctrines with the Platonic ones, in endorsing explicitly the teachings of Arabic or, even worse, Pagan Neoplatonism. ${ }^{46}$ It might be perhaps more than a curiosity to add that a Kabbalist with Platonic sympathies, one of the teachers of Giles of Viterbo, ${ }^{47}$ a famous Jewish convert, Felix Pratensis (Felice da Prato), obtained from the authorities in Venice in 1515 the permission of printing two Latin translations of kabbalistical works: the already mentioned Imre shefer of Abraham Abulafia and the Sefer ha-temunah, where the doctrine of the shemittot (world cycles) and of the periodical apocatastasis is overtly taught, exactly the doctrinal tenets against which Del Medigo was battling.

It is perhaps interesting to note that Pico himself commented upon the Liber de causis in his 900 theses, attributing them, uniquely, to the Arab "Abucaten Avenan", identified by Mauro Zonta as the Christian translator of the Theologia Aristotelis into Arabic, Abu-Katm ibn-Na'ima al-Himși, ${ }^{48}$ and in one of his theses, he expanded precisely about the proposition on the ineffability of the first Cause. ${ }^{49}$ But Pico was certainly aware that Plato (or Aristotle) was not the

43 A blank space is left in place of the expected number of the sefirot.

44 A first partial edition of the letter has been published by Dukas 1876; see also Giovanni Pico della Mirandola, De dignitate hominis, p. 67-72; the letter has been edited integrally by Kieszkowski 1964, p. 63-75. As it is well known, Kieszkowski's edition is not completely reliable, I have therefore based the excerpt quoted above on a direct reading of the manuscript, underlining the words which differ from his edition. See now Licata 2017, p. 122.

45 Pace Bland.

46 Cfr. Idel 1992.

47 Cfr. Kahle 1954, p. 50-74. See also Stern 2011, p. 76-108.

48 Zonta 1998, p. 323-330.

49 In the fifth thesis according to the Liber de causis, he writes: Cum dicit Abucaten causam primam superiorem esse omni narratione, non tam propter id habet veritatem quod primo affert, quia scilicet causam ante se non habet, quam propter id quod secundario innuit, quia omne intelligibile unialiter antecedit. I quote here the translation by Farmer 1998, p. 463: "When Abucaten said that the first cause is superior to all speech, this is not true so much because of what he affirms first, namely since it has no cause before itself, but because of what he suggests second, because it is unially antecedent to everything intelligible". 
author of the Liber de causis. Moreover, as I have pointed out elsewhere, ${ }^{50}$ also his translator, the Jewish convert Flavius Mithridates, responsible for the Latin version of a large kabbalistic library, seems to recur to the language of the Liber de causis for interpreting kabbalistic language, for instance in rendering the תשובה Hebrew, one of the names of the last sefirah (Malkut) not, as usual, with conversio, but with the Latin reiteratio, an expression, and a concept behind it, which is tightly related to $\S 14(15)$ of the Liber de causis. ${ }^{51}$ This kind of implicit quotation, however, is highly problematic since Mitrhidates, defined once a legitimus Platonis amicus by Ficino, ${ }^{52}$ was versed in Neoplatonic philosophy. The contamination of sources makes often the quest for authentic traces of the Liber de causis in Humanistic philosophy, no less than in Christian Kabbalah a desperate enterprise. As it will become clear in the next chapter, reading Medieval metaphysics with Renaissance glasses is a constant temptation, sometimes even a necessity, but it implies quite remarkable philological costs.

\section{Back to the Beginning}

Ironically, there seems to be few ways of reading Medieval kabbalistic texts without recurring to their Humanistic reception. Among Mithridates' translations for Giovanni Pico della Mirandola one finds ${ }^{53}$ a treatise bearing the Latin title Questiones super decem sefirot cum responsionibus suis, which is the interpretation of one of the titles with which this fortunate booklet is known in Hebrew manuscripts שאלות ותשובות על עשר ספירות (Sheelot u-teshuvot 'al 'eser sefirot) by the Geronese Kabbalist 'Azri'el of Gerona (116o-1238), who wrote his foundational commentaries and tracts before the first (known) Hebrew translation of the Liber de causis was accomplished. In this "catechism," an imaginary dialogue is depicted between a Kabbalist and a "questioner," someone who is in search of truth, a philosopher in the most basic sense. The questions and the answers proceed from the existence of God to the explanation of the single sefirot, having recourse not primarily to the authority of the Bible or to some secret revelation, but to allegedly stringent rational arguments. The first two

50 Cfr. Campanini 2005, p. 76; see also Menahem Recanati, Commentary on the Daily Prayers, p. 123-124.

$51 \quad$ Liber de causis, $\mathrm{XIV}(\mathrm{XV})$ : Omnis sciens quiscit essentiam suam est rediens ad essentiam suam reditione completa.

52 Cfr. Kristeller 1937, p. 35.

53 In the ms. Vat. Ebr. 190 of the Vatican Library, f. 165r-173v; cfr. Campanini 2002, p. 9o-96 and Campanini 2020. 
of these questions, before delving into the technicalities of kabbalistic lore, contain very general statements on the nature of God, and repeatedly 'Azri'el quotes the חכמי המחקר (chakme ha-mechqar), the "Philosophers"54 or the wise inquirers, as opposed to the חכמינו ז'ול חמיל, "our sages of blessed memory," referring to the rabbinic tradition. What is attributed to the "philosophers" comes invariably to confirm the kabbalistic doctrine presented by 'Azri'el. For example, in the answer to the first question, concerning the existence of God, we read:

ומה שהוא נעלם אין קץ ותכלית ואין לו חקר ואין חוץ ממנו. וחכמי המחקר מודים בזה

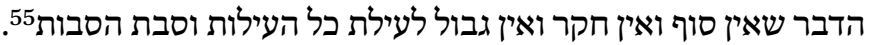

[That which is hidden is without end and limit; it is unfathomable and nothing exists outside it. The philosophers admit to this fact that the Cause of all causes and the Origin of origins is infinite, unfathomable, and without limit. ${ }^{56}$ ]

It seems apt to quote, here and in the following instances, Flavius Mithridates' translation as well:

... quod autem ocultatur neque habet finem neque terminum neque consumationem neque investigationem, nec est extra se. Sapientes autem inquisitores concedunt hoc scilicet in re non habente finem nec terminum nec investigationem et vocant eum causam causarum seu adinventionem adinventionum. ${ }^{57}$

Again, in the answer to the second question, a statement concerning negative theology is attributed to the 'philosophers':

\section{וחכמי המחקר מודים לדברי האומר כי אין השגתינו כי אם על דרך לא58}

[Furthermore, the philosophers are in agreement that our perception of Him cannot be except by way of negative attribution. $\left.{ }^{59}\right]$

54 According to the translation of Ronald C. Kiener, in Dan 1986, p. 89-96.

55 'Azri'el of Gerona, Perush 'eser sefirot, in Ibn Gabbay 1850, f. 2 r.

56 Dan 1986, p. 89.

57 Ms Vat. Ebr. 19o, f. 165 r.

$5^{8}$ 'Azri'el, Perush, f. 2 r.

59 Dan 1986, p. 9 o. 
Et sapientes inquisitores concedunt verba dicentis quod non est comprehensio nostra nisi per viam non. ${ }^{60}$

A third instance, found in the answer to the seventh question, is less specific, but still deserves some consideration:

וחכמי המחקר אמרו כי שכל האדם יש לו גבול ומדרך המנה[י]ג אנו רואים כי כל דבר יש לו גבול ושעור ומדמרה אמרו כישי.61.

[Finally, the philosophers stated that man's intellect is finite, and that from the way of the Ruler we see that everything has limitation, magnitude, and measure. ${ }^{62}$ ]

Sapientes autem inquisitores dixerunt quod intellectus hominis habet terminum, de more autem consuetudinis est dicere quod videmus quod omnis $^{63}$ res habet terminum quantitatem discretam et mensuram. ${ }^{64}$

One could point to several analogies with the style of thought of the Liber de causis, but, admittedly, these are too generic elements for building on their basis a philological argument in order to state without doubts that 'Azri'el read approvingly the Liber de causis, or, for that matter, that he was indirectly influenced by that booklet. That a certain familiar similarity is recognizable between the Liber de causis and these texts is rather undeniable, but it is quite a modest result. More interesting for our purpose is the carefully chosen terminology of our kabbalist, who, in two out of three references to the "wise men" or "the philosophers" uses the verb מודים (modim), that is "they admit," or "confess," a rather polemical, or rhetorically astute, lexical choice, in order to prevent any possible confessional or theological objection, both from the interlocutor, who seems to be rather inclined to dialectical argumentation than to ex auctoritate tirades and, even more, from the readers.

The peculiar character of these passages is quite different from, to name only one example, a well-known explicit quotation of the Liber de causis (called in this instance Sefer ha-'illot), attributed to Aristotle, and inserted in a pseudo-

\footnotetext{
6 Ms Vat. Ebr. 19o, f. 165v.

61 'Azri'el, Perush, f. 3r.

62 Dan 1986, p. 93 .

63 The word omnis is written twice in the ms.

64 Ms Vat. Ebr. 19o, f. 167v.
} 
epigraphic text, the notorious Kevod ha-Shem attributed to El 'azar ha-Qallir and cited in his Commentary to the Seferyetzirah by Moshe Botarel, who wrote for a Christian patron at the end of the 14th century. ${ }^{65}$ The supposed author of the fictitious Kevod ha-Shem, Ha-Qallir, who lived in the 6th-7th century, should have quoted, according to Botarel, with absolute exactitude, the proposition 21 (20) of the Liber de causis:

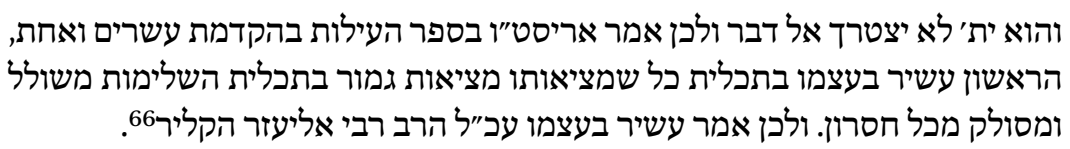

[The Lord], blessed be He, does not need anything. Therefore, Aristotle in the Book of Causes, in the proposition 21, says: "The first is rich in himself" absolutely, since his reality is perfect at the extreme degree of completeness, devoid and deprived of any need. Therefore [Aristotle] says "rich in himself." End of the quotation from R. El'azar ha-Qallir.

It seems that Botarel, who used to legitimize his own ideas attributing them pseudo-epigraphically to prestigious authors of the past, utilized the same technique also in order to quote his "Aristotelic" source, preventing thus any possible criticism for utilizing external sources and, at the same time, in writing for his Christian patron, "master John", he could point to a common source. ${ }^{67}$

Be it as it may, as Gershom Scholem has noted, ${ }^{68}$ a more subtle influence of the Liber de causis can be detected in another short treatise by 'Azri'el of Gerona, bearing the title Derek ha-emunah we-derek ha-kefirah (The way of Faith and of Disbelief ), published by Scholem himself, 69 after he had discovered it in 1938 in a manuscript ${ }^{70}$ at the Jewish Theological Seminary in New York.

The radical thought of 'Azri'el, imbibed with Neoplatonism, has fascinated many scholars since Scholem's publication but, as we will see, even before him. A systematic study of the influence of the Liber de causis and of Neoplatonic thought on this treatise is still to be done, but here I will limit myself to a quite

65 Cfr. Bardenhewer 1882, p. 321. Concerning the status quaestionis of Moshe Botarel's falsifications, cfr. Campanini 2012a.

66 Cfr. Sefer yetzirah (ed. Mantua 1562), f. 82r.

67 Provided that his Christian patron, as Botarel himself, was not aware of the fact that already Thomas Aquinas refuted Aristotle's authorship of the Liber de causis.

68 Scholem 1948, p. 140.

69 Scholem 1942, p. 207-213.

$70 \quad$ Bearing the signature JTs Mic. 1889 (Halberstam 444). 
short passage, already object of the attention of Scholem, ${ }^{71}$ Daniel Matt, ${ }^{72}$ Elliott Wolfson, ${ }^{73}$ Karl Grözinger, ${ }^{74}$ Sandra Valabrègue, ${ }^{75}$ to name only a few. ${ }^{76}$

Right at the beginning of his short treatise the Catalan kabbalist explains why the opposite ways of faith and disbelief have a common root: the believer believes in God and the denier denies God, thus in God there is the root of faith and of disbelief, since he is both "being" and "naught." In his words:

אם ישאלך היאך הוציא יש מאין והלא יש הפרש גדול בין יש לאין. השיבהו בכר אמרתי

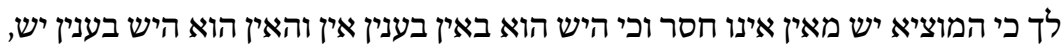
ועל זה אמרו עשה אינו ישנו ולא אמרו עשה יש מאין כדי ללמוד שהאין הוא היש והיש ביש היש

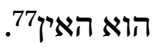

And if [the questioner] asks you: How could He draw being from nought? Is it not a great distance between the two? Answer him: I have already told you that the One who drew Being from nought does not lack anything and that Being is in Nought, according to the modality of Nought, and Nought is Being, according to the modality of Being. Concerning this it has been said: "He made his Being out of his Nought"78 and it was not said "He made Being ex Nihilo," in order to let you know that nought is Being and Being is Nought.

The point of interest, among many, in our context is the observation made by Scholem that the expression "Being is in Nought according to the modality of Nought, and Nought is Being according to the modality of Being" reminds strongly of the proposition 11 of the Liber de causis. ${ }^{79}$ Scholem deems that 'Azri'el must have had at his disposal a Hebrew translation of the Liber de causis, but the usage he made of it is quite different from the one he made of gen-

$71 \quad$ See Scholem 1956, p. 109; then in Scholem 1970, p. 78; moreover, see Scholem 1962, p. 375; English translation Scholem 1987, p. 423.

72 Matt 1990, subsequently in Fine 1995, p. 67-109.

73 Wolfson 1994.

74 Grözinger 2005, p. 243-302; see also Grötzinger 1986.

75 Valabrègue 2010.

76 One could also point to Ciucu 2010 as a good example of a research in which not the direct influence is sought, but rather the striking affinity between two ways of thinking the abysmal nature of "Nought". For the most recent edition of 'Azri'el's works, see Porat 2019.

77 Scholem 1942, p. 207.

78 Seferyetzirah 2,4 .

79 In Judah Romano's translation: אם כן העלול הוא בעלה בדרך העלה והעלה בעלול בדרך עלול (Rothschild 2013b, p. 321). 
eric Neoplatonic theologoumena, since in this case he reworks the language of his source, i.e. the terminology of the Liber de causis, in his own metaphysical reflection.

It seems appropriate at this point to ask: can the formulation used by 'Azri'el, strongly reminding the reader of the Liber de causis, be considered a full-blown quotation? Certainly not, but one could add, how would 'Azri'el quote the Liber de causis? Probably, as it was his custom, by introducing it with the expression חכמי המחקר, which constitutes in his parlance a perfect synonym for "Plato", as the following example demonstrates. In a short commentary on the prayer of the Kaddish ${ }^{80}$ the following sentence, once again a re-writing of key principles of the Liber de causis, is attributed to the חכמי המחקר:

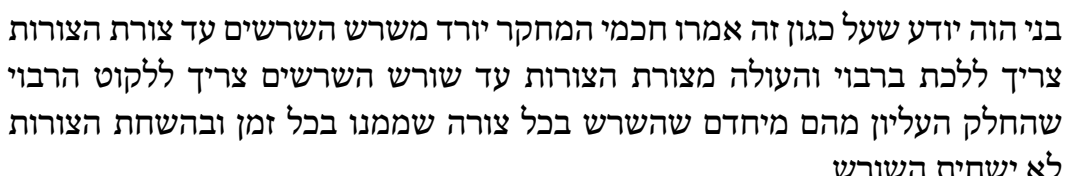

My son, you should know that the philosophers ${ }^{81}$ have said: the one who descends from the Root of the roots to the Form of forms needs to proceed by multiplying whereas the one who ascends from the Form of forms to the Root of roots needs to gather plurality [into unity], since their superior portion unites them. The root, in fact, is in every form deriving from it at any time and if you suppress the forms you do not suppress the root.

These same words appear also in 'Azri'el's commentary on the Aggadot, published, partly, by Scholem in $193 \mathrm{O}^{82}$ and more completely by Tishby. ${ }^{83}$ What is remarkable in this instance is the fact that the same quotation is now attributed "Plato". 'Azri'el even adds, after a quotation from Plato and one from Aristotle, ${ }^{84}$ the following statement:

ודברי חכמת התורה ודברי בעלי המחקר הנזכרים שניהם כאחד, דרך אחד להם ואין

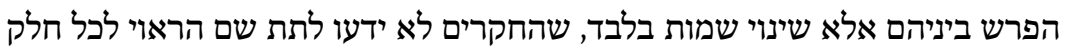

8o Published first by Scholem 1942, p. 214-216. French translation in the appendix of SédRajna 1974, p. 142-145.

81 Or 'wise inquirers'.

$82 \quad$ Scholem 1930, p. 4.

83 'Azri'el, Perush ha-aggadot, ed. 1945, p. 82-83; new ed. 1983, p. 144-145.

84 Actually, the quotation, well known in Jewish medieval literature, is from the so-called Theology of Aristotle, see Vajda 1956, p. 138-142. 


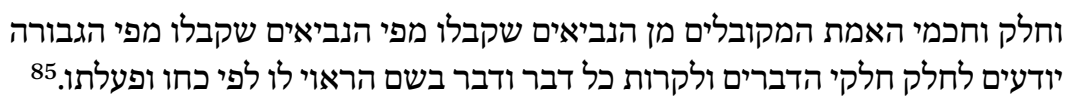

The words of the Wisdom of the Law and the words of the philosophers I have recalled converge, they follow the same path and there is no difference between them except for terminology only since the philosophers do not know how to name the single parts, whereas the wise men of truth who received (ha-mequbbalim) [their wisdom] from the prophets, who received [their inspiration] from the Almighty are knowledgeable about every single component of reality and can name exactly everything according to its virtue and its action.

The difference between philosophers and kabbalists is in the names, albeit not a nominalistic one: they differ rather in the very essence, which is, for Judaism, an ineffable Name. In this difference one should perhaps search for traces of the Liber de causis in early kabbalistic literature, without forgetting that the short treatises of 'Azri'el do not form the core of kabbalistic literature "per se". They are a prominent example of a quite different literary genre, very much inspired by philosophical style, that is kabbalistic apologetics. Within its boundaries, and only there, as it has been shown, an explicit or even implicit reference to the breviary of Neoplatonism in the Middle Ages makes sense. In other words: allusions or quotations of the Liber de causis are easily retrievable whenever the kabbalists recur to the apologetic mode, but in the core of their literary production these traces are virtually absent or they are not clearly recognizable.

It is not by mere chance, thus, that the subsequent approaches to Kabbalah from an external point of view were particularly interested in Neoplatonic analogies, and found a special interest precisely in passages where the kabbalists did paraphrase the Liber de causis. A particularly relevant case in point is of course the German humanist Johannes Reuchlin, who in his De arte cabalistica (1517), copied the aforementioned passage of 'Azri'el about Being and Nought, enhancing that he was strikingly reminded of the De docta ignorantia of Cusanus, which for him meant the most enthusiastic approval. ${ }^{86}$ The discovery of the same in the other, the pleasant effect of finding out that the kabbalist had read the same books as his own intellectual references is a beautiful demonstration of the potential and of the limits of any cultural encounter. As it is known, Scholem was thinking of Reuchlin when he found in New York the kabbalistic

85 Scholem 1930, p. 4-5; 'Azri'el, Perush ha-aggadot, ed. 1945, p. 83; new ed. 1983, p. 145.

86 I have expanded on this subject in Campanini 2o12b. 
source he was quoting, to his philological satisfaction. ${ }^{87}$ The Liber de causis represents, in this exemplary case, the connecting source (the root) explaining analogies between heterogeneous textual traditions. On the other hand, its pervasive character runs the risk of impoverishing the significance of its very presence.

Philosophy and philology follow two diametrically opposed vectors: philology, especially in the case of the Liber de causis is in search of an archetype (be it Proclus, Plotinus or even Plato himself, but nothing forbids to tend to even higher points in time), whereas history of philosophy, commenting a commentary, proceeds towards the latest manifestation of an idea, the function and understanding of a concept. Reading the Liber de causis in medieval Jewish mysticism, or rather in its apologetical dimension, seems possible only through the prism of the Renaissance.

To study the reception of a Pagan work within a religious current such as Kabbalah implies two different aspects: an apologetic bent, which provides the suitable context for any explicit reference to the Liber de causis, otherwise disguised to the point of being unrecognizable, and a philosophical-philological endeavour. The latter, as I have tried to show, bears in itself the seed of contradiction, as Kabbalah as a religious doctrine implies in itself. Kabbalah is taken to mean "reception" and the kabbalists purport to unearth the authentic meaning of tradition but, fatally, as the newest commentary, ontologically belated, as it were. Philology attempts, at times with remarkable success, to reconstruct the "original" source of the Liber de causis, whereas the kabbalists are rather interested in the result, the mouth of the river, in keeping with the fluvial metaphor. Ideologically, Kabbalah does not need the Liber de causis, and not even negative theology, but is ready to use it for apologetic purposes, to defend ad extra its ineffable contents.

As Franz Rosenzweig, ${ }^{88}$ who reflected with lucidity on Jewish apologetics, ${ }^{89}$ in his metaphysics once remarked: "About God we know nothing. But this not-knowing is a not-knowing about God".90 The analogy with 'Azrie'l's way of speaking, if not of thinking, becomes clear a few sentences further: "God could no longer be defined, therefore, other than by his totally undefinable nature. This way that leads from a found something to the nothing at the end of which

\footnotetext{
$87 \quad$ Cfr. Scholem 197ob.

88 Concerning the hypothetical role of Kabbalah in Rosenzweig's thought, see Idel 1988, updated in Idel 2010, p. 159-167; Harvey 1987; Lucca 2012, p. 1-6 (text), 7-19 (introduction).

89 Rosenzweig 1923.

9o Rosenzweig 1921, p. 32: "Von Gott wissen wir nichts. Aber dieses Nichtwissen ist Nichtwissen von Gott"; English translation (by Barbara E. Galli) in Rosenzweig 2005, p. 32.
} 
atheism and mysticism can shake hands is not the way we are taking; we are instead taking the way leading from the nothing to the something". ${ }^{91}$ But even if one is firmly decided to take the descending path, from Nought to Being, the Nought, as its cause, pervades Being. The authentic reception of the Liber de causis in Kabbalah seems to escape philological examination, since Kabbalah, by its very nature, could only quote it as a convenient analogy found in external, i.e. non Jewish, thought but, in a constructive way, would absorb its aphorisms only by effacing their traces and effectively dissolving them.

\section{Bibliography}

\section{Manuscripts Consulted}

Berlin, Staatsbibliothek, Hebr. Qu. 832

Mantua, Biblioteca Comunale, ms. ebr. 21

Munich, Bayerische Staatsbibliothek, Hebr. 285

Oxford, Bodleian Library, Mich. 335 (olim 82)

Paris, Bibliothèque Nationale de France,

hébr. 849

hébr. 968

hébr. 6508

Vaticano (Città del), Biblioteca Apostolica

Ebr. 190

\section{Primary Sources}

Abraham ben Samuel Abulafia, Imre shefer, ed. A. Gross, Jerusalem, Aharon Barazani, 1999 .

Averroes, Tahafut al-Tahafut (Incoherence of the Incoherence), ed. and transl. S. Van den Bergh, Cambridge, Cambridge University Press, 1987.

'Azri'el, Perush ha-aggadot, ed. I. Tishby, Jerusalem, Mekize Nirdamim, 1945. New ed. Jerusalem, Magnes, 1983.

'Azri'el, Le commentaire sur la liturgie quotidienne, ed. G. Séd-Rajna, Leiden, Brill, 1974. Flavius Mithridates, The Book of Bahir. Flavius Mithridates' Latin Translation, the Hebrew Text, and an English Version, ed. S. Campanini, Torino, Aragno, 2005.

91 Rosenzweig 1921, p. 32: “(...) Gott also bestimmbar wurde nur in seiner völligen Unbestimmbarkeit. Diesen Weg, der von einem vorgefundenen Etwas zum Nichts führt und an dessen Ende sich Atheismus und Mystik die Hand reichen können, beschreiten wir nicht, sondern den entgegengesetzten vom Nichts zum Etwas". 
Giovanni Pico della Mirandola, De dignitate hominis, Heptaplus, De ente et uno e scritti vari, ed. E. Garin, Firenze, Vallecchi, 1942.

Hillel von Verona, Über die Vollendung der Seele, ed. Y. Schwartz, Freiburg im Breisgau, Herder, 2009.

Isaac Abravanel, Perush 'al ha-torah, Venezia, Bragadin, 1579.

Joseph Del Medigo, Sefer novelot chokmah, Basel [= Hanau], 1631.

Liber de causis - "Le Liber de causis. Édition établie à l' aide de 90 manuscrits," in Tijdschrift voor Philosophie, 28 (1966), p. 90-203; repr. in A. Pattin, Miscellanea. I. Liber de causis, Leuven, Bibliotheek van de Faculteit der Godgeleerdheid, 2000.

Liber de causis -Die pseudo-aristotelische Schrift Über das reine Gute bekannt unter dem Namen Liber de causis, ed. O. Bardenhewer, Freiburg im Breisgau, Herder'sche Verlagsbuchhandlung, 1882.

Liber de causis-Pseudo-Aristoteles Liber de causis. Zarachia b. Izsák által eszkölt héber forditásának kritikai össezehasonlitása az arab ereditevel, a latin és a többi héber forditások figyelembevételével, ed. I. Schreiber, Budapest, Atheneum, 1916.

Menahem Recanati, Commentary on the Daily Prayers. Flavius Mitrhridates'Latin Translation, the Hebrew Text, and an English Version, ed. G. Corazzol, vol. I, Torino, Aragno, 2008.

Sefer Yetzirah see Campanini 2012a.

\section{Secondary Sources}

Bardenhewer, O. (1882) see Liber de causis.

Busi, G. (2006), "Who does not wonder at this Chameleon? The kabbalistic Library of Giovanni Pico della Mirandola," in G. Busi (ed.), Hebrew to Latin-Latin to Hebrew. The Mirroring of Two Cultures in the Age of Humanism, Torino, Aragno, p. 167-196.

Busi, G. (2007), L'enigma dell'ebraico nel Rinascimento, Torino, Aragno.

Bland, K.P. (1991), "Elijah del Medigo's Averroist Response to the Kabbalahs of Fifteenth Century Jewry and Pico della Mirandola," in Jewish Thought and Philosophy 1, p. 2353 .

Campanini, S. (2002), "Pici Mirandulensis bibliotheca cabbalistica latina. Sulle traduzioni latine di opere cabbalistiche eseguite da Flavio Mitridate per Pico della Mirandola," in Materia Giudaica, 7,1, p. 9o-96.

Campanini, S. (2012a), "On Abraham's Neck. The Editio Princeps of the Sefer Yetzirah (Mantua 1562) and Its Context," in G. Veltri, G. Miletto (eds), Rabbi Judah Moscato and the Jewish Intellectual World of Mantua in the 16th-17th Centuries, Leiden / Boston, Brill, p. 253-278.

Campanini, S. (2012b), "Die Hybris des Juden. Alle origini della teologia sabbatiana di Gershom Scholem," in E. D’Antuono, I. Kajon, P. Ricci Sindoni (eds), Giacobbe e l'angelo. Figure ebraiche alle radici della modernità europea, Roma, Lithos, p. 211235 . 
Campanini, S. (2020), "Color azurei oscurissimi. Sfumature cabbalistiche in 'Azriel di Gerona e Flavio Mitridate", in Itinera 19, p. 54-71.

Ciucu, C. (2010), "Les penseurs du néant: Heidegger et la mystique juive du Moyen Age," in $\operatorname{Yod}_{15}$, p. 215-233.

Coriat, J. (1839), Ma’or we-shemesh, Livorno, Eli'ezer Menachem Ottolenghi.

Dan, J. (1986), (ed.), The Early Kabbalah, New York / Mahwah, Paulist Press.

Dukas, J. (1876), Recherches sur l'histoire littéraire du quinzième siècle, Paris, Léon Techener.

Farmer, S.A. (1998), Synchretism in the West: Pico's goo Theses (1486), Tempe, Medieval and Renaissance Text and Studies.

Fine, L. (1995), Essential Papers on the Kabbalah, New York, New York University Press. Grötzinger, K. (1986), "Theosophie, Historiosophie und ,Anthroposophie' des Kabbalisten Azriel aus Gerona (13. Jh.)," in Frankfurter judaistische Beiträge 14, p. 111-151.

Grözinger, K. (2005), Jüdisches Denken. Bd. II Von der mittelalterlichen Kabbala zum Hasidismus, Frankfurt am Main, Campus Verlag.

Harvey, W.Z. (1987), "How much Kabbalah in the Star of Redemption?," in Immanuel 21, p. $128-134$.

Ibn Gabbay, M. (1850), Derek emunah, Berlin, Kornegg.

Idel, M. (1982), "Ha-perush ha-magi we-ha-neoplatoni shel ha-qabbalah bi-tequfat haRenaissance," in Jerusalem Studies in Jewish Thought 1, p. 6o-112

Idel, M. (1983), "The Magical and Neoplatonic Interpretations of the Kabbalah in the Renaissance," in B.D. Cooperman (ed.), Jewish Thought in the Sixteenth Century, Cambridge, Harvard University Center for Jewish Studies, p. 186-242, reprinted in D.B. Ruderman (ed.), Essential Papers on Jewish Culture in Renaissance and Baroque Italy, New York, New York University Press 1992.

Idel, M. (1988), "Franz Rosenzweig and the Kabbalah," in P. Mendes Flohr (ed.), The Philosophy of Franz Rosenzweig, Hanover-London, New England University Press, p. $162-171$.

Idel, M. (1992), "Jewish Kabbalah and Platonism in the Middle Ages and Renaissance," in L.E. Goodman (ed.), Neoplatonism and Jewish Thought, Albany, S UnY Press, p. 319351.

Idel, M. (2010), Old Worlds, New Mirrors. On Jewish Mysticism and Twentieth-Century Thought, Philadelphia, University of Pennsylvania Press.

Idel, M. (2016), Il male primordiale nella Qabbalah, Milano, Adelphi.

Kahle, P. (1954), "Zwei durch Humanisten, dem Papst gewidmete Ausgaben der hebräischen Bibel," in Essays Presented to Leo Baeck on the Occasion of His Eightieth Birthday, London, East and West Library, p. 50-74

Kieszkowski, B. (1964), "Les rapports entre Elie del Medigo et Pic de la Mirandole (d'après le ms. lat. 6508 de la Bibliothèque nationale)," in Rinascimento 15, p. 4191. 
Kristeller, P.O. (1937), Supplementum Ficinianum. Marsilii Ficini philosophi platonici opuscula inedita et dispersa, vol. I, Firenze, Olschki.

Licata, G. (2017), "Magno in secta peripatetica. Una nuova edizione commentate della lettera di Elia del Medigo a Giovanni Pico della Mirandola (Paris, BnF, ms. lat. 6508)," in Schede Medievali 55, p. 103-143.

Lucca, E. (2012), "Gershom Scholem on Franz Rosenzweig and the Kabbalah," in Naharaim 6,1, p. $7-19$.

Matt, D. (1990), "Ayn: The Concept of Nothingness in Jewish Mysticism," in R.K.C. Forman (ed.), The Problem of Pure Consciousness, Oxford / New York, Oxford University Press, p. 121-159.

Neubauer, A. (1886), Catalogue of the Hebrew Manuscripts in the Bodleian Library, Oxford, Clarendon Press.

Ogren, B. (2016), The Beginning of the World in Renaissance Jewish Thought. Ma'aseh Bereshit in Italian Jewish Philosophy and Kabbalah, 1492-1535, Leiden / Boston, Brill.

Porat, O. (2019), Machbarot R. 'Azriel ish Gerona, Los Angeles, Cherub Press.

Richler, B. (2012), "Steinschneider's Manuscripts," in R. Leicht, G. Freudenthal (eds), Studies on Steinschneider. Moritz Steinschneider and the Emergence of the Science of Judaism in Nineteenth Century Germany, Leiden / Boston, Brill, p. 301-318.

Rosenzweig, F. (1921), Stern der Erlösung, Frankfurt am Main, Kauffmann Verlag.

Rosenzweig, F. (1923), "Apologetisches Denken," in Der Jude, 7/7-8, p. 457-464.

Rosenzweig, F. (2005), The Star of Redemption, Madison, University of Wisconsin Press.

Rothschild, J.-P. (2013a), "Le Livre des Causes du latin à l'hébreu: textes, problèmes, réception," in A. Fidora, H. Hames, Y. Schwartz (eds), Latin into Hebrew. Texts and Studies, Volume II: Texts in Context, Leiden / Boston, Brill, p. 47-84.

Rothschild, J.-P. (2013b), "Les traductions hébraïques du Livre des causes latin," in A. Fidora, H. Hames, Y. Schwartz (eds), Latin into Hebrew. Texts and Studies. Volume II: Texts in Context, Leiden / Boston, Brill, p. 289-387.

Ruderman, D. (1988), Kabbalah, Magic, and Science:The Cultural Universe of a SixteenthCentury Jewish Physician, Cambridge (Mass.) / London, Harvard University Press.

Scholem, G. (1930), Catalogus codicum cabbalisticorum Hebraicorum, quot [sic] conservantur in Bibliotheca Hierosolymitana, Jerusalem, The Hebrew University.

Scholem, G. (1931), Peraqim le-toledot sifrut ha-qabbalah, Jerusalem, Azriel.

Scholem, G. (1942), "Seridim chadashim mi-kitve R. 'Azri'el mi-Gerona," in Sefer zikkaron le-Asher Gulak we-li-Shemuel Klein, Jerusalem, The Hebrew University, p. 201222.

Scholem, G. (1948), Reshit ha-qabbalah, Tel Aviv, Schocken.

Scholem, G. (1956), "Schöpfung aus dem Nichts und Selbstverschränkung Gottes," in Eranos Jahrbuch 25, p. 87-119.

Scholem, G. (1962), Ursprung und Anfänge der Kabbala, Berlin, De Gruyter.

Scholem, G. (1964), "Das Ringen zwischen dem biblischen Gott und dem Gott Plotins in der alten Kabbala," in Eranos Jahrbuch 33, p. 9-50 
Scholem, G. (1970a), Über einige Grundbegriffe des Judentums, Frankfurt am Main, Suhrkamp.

Scholem, G., (1970b), "Die Erforschung der Kabbala von Reuchlin bis zur Gegenwart," in Id., Judaica 3. Studien zur jüdischen Mystik, Frankfurt am Main, Suhrkamp, p. 247263.

Scholem, G. (1987), Origins of the Kabbalah, Philadelphia, The Jewish Publication Society.

Steinschneider, M. (1869), Alfarabi (Alpharabius). Des arabischen Philosophen Leben und Schriften, mit besonderer Rücksicht auf die Geschichte der griechischen Wissenschaft unter den Arabern, St. Petersbourg, Académie Impériale des sciences.

Steinschneider, M. (1875), Die hebräischen Handschriften der K. Hof- und Staatsbibliothek in Muenchen, München, In Commission der Palm'schen Buchhandlung.

Steinschneider, M. (1895), Die hebräischen Handschriften der K. Hof- und Staatsbibliothek in Muenchen. Zweite, grossen teils umgearbeitete und erweiterte Auflage, München, In Commission der Palm'schen Buchhandlung.

Steinschneider, M. (1897), Verzeichnis der Handschriften der königlichen Bibliothek zu Berlin, vol. II, Berlin, A. Asher \& Co.

Stern, D. (2011), "The Rabbinic Bible in Its Sixteenth-Century Context," in J. Hacker, A. Shear (eds), The Hebrew Book in Early Modern Italy, Philadelphia, University of Pennsylvania Press, p. 76-108.

Vajda, G. (1954), Juda ben Nissim ibn Malka, philosophe juif marocain, Paris, Larose.

Valabrègue, S. (2010), Be-nistar u-ve-nigleh: En Sof ba-qabbalah ha-teosofit (Concealed and Revealed: Eyn Sof in Theosophic Kabbalah), Los Angeles, Cherub Press.

Vajda, G. (1956), "Un chapitre de l' histoire du conflit entre la kabbale et la philosophie. La polémique anti-intellectualiste de Joseph ben Shalom Ashkenazi de Catalogne," in Archives d'histoire doctrinale et littéraire du Moyen-Age 31, p. 45-144.

Wolfson, E.R. (1994), "Negative Theology and Positive Assertion in the Early Kabbalah," in Daat 32, p. V-XXII.

Zonta, M. (1998), "L'autore del De causis pseudoaristotelico: una nuova ipotesi," in R.B. Finazzi, A. Valvo (eds), La diffusione dell'eredità classica nell'età tardoantica e medievale. Il Romanzo di Alessandro e altri scritti, Alessandria, Edizioni dell'Orso, p. 323-330. 